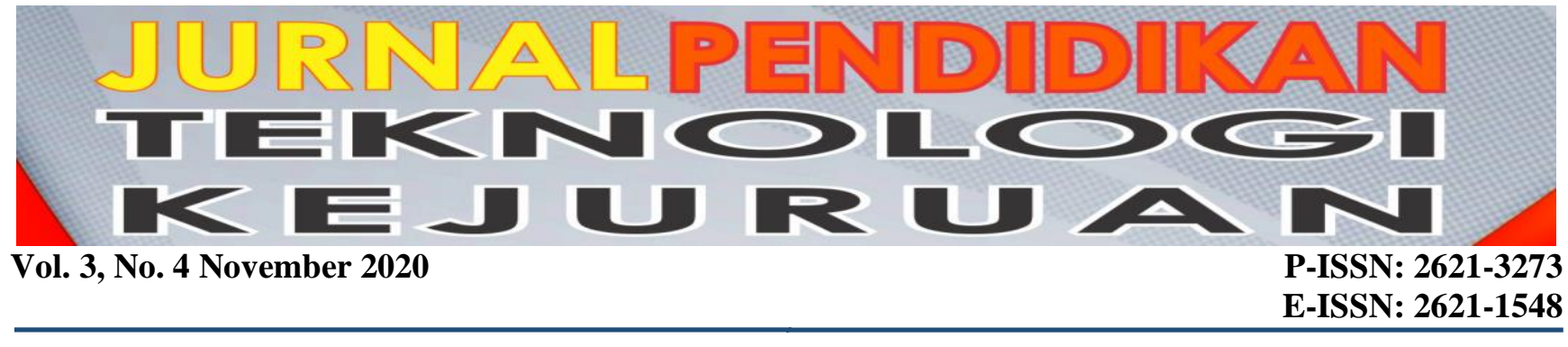

\title{
Analysis of The Factors that Affect Employee Turnover Intention at Travelodge Hotel Batam
}

\author{
Ulfa $^{1}$, Youmil Abrian ${ }^{2 *}$, Arif Adrian ${ }^{3}$ \\ ${ }^{1,2,3}$ Department of Tourism, Universitas Negeri Padang \\ "Corresponding author, e-mail: abrian.yomil@ fpp.unp.ac.id
}

\begin{abstract}
The study aims to determine the analysis of factors influencing Turnover Intention employees at Hotel Travelodge Batam. This research is a quantitative descriptive type with a factor analysis method aimed at seeing the factors affecting Turnover Intention in the Hotel Travelodge Batam. The population in this study is all employees amounting to 52 people, the sample in this study is with non-probability sampling technique with a total saturated sample of 52 people. Data analysis techniques using SPSS version 16.00. The results of this study showed a simple linear regression hypothesis test obtained F 5,418 with sig. $0.000<0.05$, then the variable factors that influence can explain the turnover variable intention employees significantly, with the value of $R$ Square of 0.419 . This means that the factors influencing the turnover of intention employees by $41.9 \%$ and $58.1 \%$ are influenced by other factors. The salary factor has no significant effect on turnover intention. Training factors and work facilities have no significant effect on turnover intention. Leadership factors have no significant effect on turnover intention. The award factor has significant effect on turnover intention. The organizational culture factor has no significant effect on turnover intention. Job satisfaction factor has no significant effect on turnover intention. Based on the results the research researchers suggested to pay more attention to factors that influence employee turnover and further improve job satisfaction, training and work facilities,.
\end{abstract}

Keywords : Factor Analysis , Turnover Intention, Employee, Hotel

\section{INTRODUCTION}

Human resources in the hotel industry are managed in an organized manner starting from recruitment, selection, placement, training, which will affect future company performance. However this is also undeniable, human resources that have been managed well are not free from various problems. The high level of turnover intention is a problem that is often encountered in organizations, especially in the hotel industry. The high turnover rate is a very important problem, because indirectly high turnover can hinder the work productivity of companies in achieving their goals. Job satisfaction of employees who still live in the company will decrease, and trigger a negative view or get a bad image about the company experiencing turnover.

The high level of turnover intention for employees leaving the Travelodge Batam Hotel per year can be seen from the annual turnover of employees who leave. The phenomenon of finding this problem is due to the desire to move to another place driven by problems encountered by employees in their work environment. This can be seen from the slow pace of the work system due to frequent employee changes. The problem that occurs here is the high workload of employees who still live at the Travelodge Batam hotel, and it causes many employees to complain while working and employees also show lazy behavior or attitudes at work.

The higher the turnover intention, the more frequent employee turnover occurs. And this will hurt the company. If this turnover intention is allowed, it will certainly have a negative effect on the company, such as a decrease in employee performance and the transfer of employees to other companies

If an employee leaves the company, he will answer the following problems:

1. The high level of employee turnover intention at the Travelodge Batam Hotel.

2. High employee workload.

3. The presence of employees in and out of employees, which hinders hotel operations.

4. The lack of promotion opportunities for employees who have worked for a long time.

According to (Mobley, 2012) the factors that affect turnover intention are organizational culture, leadership style, compensation, job satisfaction, 
career, environmental aspects. The hotel industry which is the object of this research is the Travelodge Batam Hotel. There are factors that affect employee turnover intention, it is hoped that the company can retain its employees, so that the turnover intention rate in the company decreases. The decrease in turnover intention can properly control the operation of operations. This research focuses on six variables which are the factors that influence turnover intention, namely organizational culture, leadership style, compensation, job satisfaction, career, and other job alternatives.

The formulation of the research problem is: 1) What factors cause employee turnover intention at the Travelodge Batam Hotel? 2) How much do these factors effect on employee turnover intention at the Travelodge Batam Hotel?. Whether or not the influence of these factors is significant on employee turn over intention at Travelodge Hotels based on a significant level that is smaller than 0.05

\section{METHOD}

\section{A. Research purposes}

the purpose of this research is: 1) Analyze what factors are the cause of employee turnover intention at the Travelodge Batam Hotel. 2) Analyze how much do these factors have influence on employee turnover intention at the Travelodge Batam Hotel.

\section{B. THEORETICAL BASIS}

1. Turnover Intention

According to (Rivai ,2011: 238), "Turnover intention is a desire to quit working voluntarily from one place to another". It can be concluded that turnover intention is the desire to leave a job either voluntarily or not, and an intention arises to find a job according to one's own wishes.

Turnover is the tendency or intensity of individuals to leave the organization for various reasons and among them the desire to get a better job, (Hasibuan, 2011)

2. Organizational culture

The values of a strong organizational culture can create an environment that is conducive to building and improving quality in a sustainable manner. Adhesives that can unite a company to be united. Organizational culture is a set of value systems, norms that have long been valid, agreed upon and followed by organizational employees as a code of conduct and solving organizational problems (Sutrisno, 2010).

3. Leadership Style
According to (Griffe and Hom, 2010), research identifies the factors that affect turnover intention, one of which is leadership style.

4. Compensation

According to (Hasibuan, 2011: 118) compensation is income in the form of money and goods, either directly or indirectly, received by employees in the form of compensation for services provided to the company.

5. Satisfaction Work

According to (Wibowo, 2013: 501), job satisfaction will affect the productivity expected by managers, therefore managers must understand employees to increase employee job satisfaction.

6. Career

(Mathis John H. Jackson, in Setyawati, 2013) states that the definition of career is a series of positions related to the work occupied by a person throughout his life.

7. Environmental Aspects

The work environment is the entire tooling and materials faced, the surrounding environment in which a person works, his work methods, and work arrangements both as individuals and as a group, according to (Sedarmayanti, 2011).

\section{Methodology}

This research belongs to the descriptive quantitative type with the causal associative method. The population of this study were all employees of the Travelodge Batam Hotel. Data collection through questionnaires with the help of a Likert scale, (Sugiyono 2013). The analysis technique of this research uses factor analysis and linear regression. Then the analysis requirements test is normality test, multicollinearity, heteroscedasticity and hypothesis testing using multiple linear regression to see the influence of factors that affect employees on turnover intention.

The results validity and Relibiality teat of the research from 35 statement indicators were declared valid. By using the software SPSS 16. And the results of the reliability stated that the reliability is greater than 0.60 which is equal to 0.654 which means that all variables are declared reliable. 


\section{RESULT}

\section{Factor analysis}

\section{Table 1}

KMO and Bartlett's Test

\begin{tabular}{|ll|l}
\hline Kaiser-Meyer-Olkin Measure of Sampling Adequacy. & .721 \\
Bartlett's Test of Approx. Chi-Square & 521,328 \\
Sphericity & Df & 190 \\
& Sig. & 0.000 \\
\hline
\end{tabular}

The KMO and Bartlett Test numbers are 0.721 , the significance level is $0.000<0.05$, so the existing variables and samples can be analyzed further. Regarding the number of factors formed after seeing the MSA, there are 20 indicators, it can be seen the number of factors formed from the following table:

Table 2

Determination Number of Factors

\begin{tabular}{|c|c|c|c|}
\hline \multirow{2}{*}{ Component } & \multicolumn{3}{|c|}{ Initial Eigenvalues } \\
\cline { 2 - 4 } & Total & \% of Variance & Cumulative\% \\
\hline 1 & 5,631 & 28,153 & 28,153 \\
\hline 2 & 3,016 & 15,080 & 43,232 \\
\hline 3 & 1,834 & 9,171 & 52,403 \\
\hline 4 & 1,691 & 8,453 & 60,856 \\
\hline 5 & 1,191 & 5,953 & 66,809 \\
\hline 6 & 1,094 & 5,468 & 72,277 \\
\hline
\end{tabular}

Extraction Method: Principal Component Analysis.

Table 3

Analysis Results Matric Factor

\begin{tabular}{|c|c|c|c|c|c|c|c|c|}
\hline Name Factor & Covered Indicators & $\begin{array}{l}\text { Loading } \\
\text { Value }\end{array}$ & \multicolumn{6}{|c|}{$\begin{array}{l}\text { can be concluded that the regression model does not } \\
\text { occur heteroscedasticity. } \\
\text { 4). Hypothesis test } \\
\text { With ANOVA test results regarding employee } \\
\text { soft skills and employee performance can be seen in } \\
\text { the table below: } \\
\text { Table } 4 \\
\text { ANOVA }\end{array}$} \\
\hline \multirow{5}{*}{$\begin{array}{l}\text { 1. Compensation } \\
\text { factor }\end{array}$} & $\begin{array}{l}\text { X } 13 \text { Salary according to } \\
\text { work results }\end{array}$ & 0.892 & \multirow{4}{*}{\multicolumn{6}{|c|}{$\begin{array}{l}\text { 4). Hypothesis test } \\
\text { With ANOVA test results regarding employee } \\
\text { soft skills and employee performance can be seen in } \\
\text { the table below: } \\
\text { Table } 4 \\
\text { ANOVA }\end{array}$}} \\
\hline & X14 Leave allowance & 0.888 & & & & & & \\
\hline & X15 Health insurance & 0.81 & & & & & & \\
\hline & $\begin{array}{l}\text { X12 Salary meets daily } \\
\text { needs }\end{array}$ & 0.786 & & & & & & \\
\hline & $\mathrm{X} 19 \mathrm{Job}$ as desired & 0.452 & & & & & & \\
\hline \multirow{3}{*}{$\begin{array}{l}\text { 2. Training and } \\
\text { work facilities } \\
\text { factors }\end{array}$} & X21 Emplovee training & 0.899 & Model & & Df & & $\mathrm{F}$ & Sig. \\
\hline & $\begin{array}{l}\text { X22 Company facilities are } \\
\text { complete and feasible }\end{array}$ & 0.795 & \multirow{3}{*}{$\begin{array}{ll}1 & \begin{array}{l}\text { Regressi } \\
\text { on }\end{array} \\
\text { Residual } \\
\text { Total }\end{array}$} & 193,223 & 6 & \multirow{3}{*}{$\begin{array}{l}32,204 \\
5,943\end{array}$} & \multirow[t]{3}{*}{5,418} & \multirow[t]{3}{*}{.000} \\
\hline & $\begin{array}{l}\text { X23 Completeness of } \\
\text { complete work }\end{array}$ & 0.721 & & 267,450 & 45 & & & \\
\hline \multirow{3}{*}{$\begin{array}{l}\text { 3. Leadership } \\
\text { factor }\end{array}$} & X7 The leader gives & & & 460,673 & 51 & & & \\
\hline & & & \multirow{5}{*}{\multicolumn{6}{|c|}{$\begin{array}{l}\text { From the table above, it is obtained that the } \mathrm{F} \\
\text { of the factors affecting employees is } 5.418 \\
\text { significant } 0.000 \text { because the significance is } \\
\text { than } 0.05 \text {, so H0 is rejected or Ha is } \\
\text { ed. It means that it can be concluded } \\
\text { aneously that there is a significant influence }\end{array}$}} \\
\hline & $\begin{array}{l}\text { X8 Joint decisions } \\
\text { X6 leader provides work } \\
\text { instructions }\end{array}$ & 0.642 & & & & & & \\
\hline \multirow{3}{*}{$\begin{array}{l}\text { 4. Award } \\
\text { factor }\end{array}$} & X18 Salary on time & 0.824 & & & & & & \\
\hline & X17 Achievement award & 0.715 & & & & & & \\
\hline & X16 Bonus & 0.553 & & & & & & \\
\hline
\end{tabular}

\begin{tabular}{|l|c|}
$\begin{array}{l}\text { X11 The leader appreciates } \\
\text { subordinates }\end{array}$ & 0.779 \\
\hline $\begin{array}{l}\text { X10 Leader provides } \\
\text { challenging jobs }\end{array}$ & 0.665 \\
\hline $\begin{array}{l}\text { X20 Support from } \\
\text { colleagues }\end{array}$ & 0.483 \\
\hline X5 Supporting facilities & 0.728 \\
\hline $\begin{array}{l}\text { X1 Two-way } \\
\text { communication }\end{array}$ & 0.672 \\
\hline $\begin{array}{l}\text { X24 Promotion is based on } \\
\text { work experience }\end{array}$ & 0.484 \\
\hline
\end{tabular}
there are 6 factors that influence employees in turnover intention at the Travelodge Batam Hotel. The formed factors are named based on the highest loading value in these factors and the meaning of the relationship of each indicator.

\section{Requirements Analysis}

\section{1). Normality test}

Based on the normality test with KolmogrovSmirnov Test obtained from the table above it can be seen that the KS probability value for all variables, both dependent and independent> alpha 0.5 , thus it can be said that all variables are normally distributed.

\section{2). Multicollinearity test}

From the Coefficient table in the Collinearity Statistics column, it can be seen that the tolerance value is close to number 1 and the VIF value $<10$, this shows that there is no multicollinearity (high correlation) between the independent variables.

\section{3). Heteroscedasticity Test}

From the research results it can be seen that the significance of all variables is greater than 0.05 , so it can be concluded that the regression model does not occur heteroscedasticity.

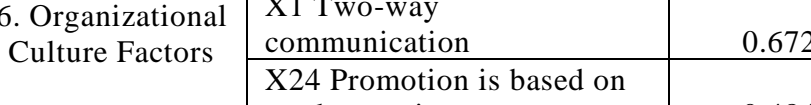

\section{.}

Based on the table above, it can be seen that 
between the variable factors of salary, training and work facilities, leadership, rewards, organizational culture, job satisfaction, on employee turnover intention at the Travelodge Batam Hotel. So that the regression model is significant or acceptable.

Table 5

Coefficient Table Variable Regression

\begin{tabular}{|l|l|l|l|l|}
\hline \multicolumn{1}{|c|}{ Model } & $\begin{array}{l}\text { Regression } \\
\text { Coefficient }\end{array}$ & $\begin{array}{l}\text { Standard } \\
\text { Error }\end{array}$ & $\begin{array}{l}\text { The } \\
\text { value } \\
\text { of t } \\
\text { count }\end{array}$ & $\begin{array}{l}\text { Level } \\
\text { Sig }\end{array}$ \\
\hline Constant & 20,543 & 8,677 & 2,368 & .022 \\
\hline X1 Salary & .009 & .174 & .050 & .960 \\
\hline $\begin{array}{l}\text { X2 Training and } \\
\text { Work } \\
\text { Facilities }\end{array}$ & -.008 & .240 & -.035 & .972 \\
\hline X3 Leadership & -243 & .285 & -.852 & .399 \\
\hline X4 Awards & $-1,067$ & .242 & $-4,417$ & .000 \\
\hline $\begin{array}{l}\text { X5 Job } \\
\text { Satisfaction }\end{array}$ & -.348 & .273 & $-1,277$ & .008 \\
\hline $\begin{array}{l}\text { X6Organizational } \\
\text { culture }\end{array}$ & -.307 & .463 &,- 664 & .510 \\
\hline $\begin{array}{l}\text { R = 0.648 F count }=5.418 \\
\text { R2 }=0.419 \text { Level sig }=0.000 \\
\text { Adjusted R Squere }=0.342\end{array}$ & & & \\
\hline
\end{tabular}

Based on the table above, the multiple regression equation is obtained as follows:

$\mathrm{Y}=20,543+0,009 \mathrm{X} 1-0,008 \mathrm{X} 2-0,243 \mathrm{X} 3-$ $1,067 \mathrm{X} 4-0,348 \mathrm{X} 5-0,307 \mathrm{X} 6$

The salary variable (X1) shows statistically insignificant results on employee turnover intention at the Travelodge Batam Hotel. This can be seen from the insignificant salary (X1) of $0.960>0.05$ with the $t$ value of 0.050 . So that the salary variable does not have a significant effect on employee turnover intention at the Travelodge Batam Hotel.

Training and work facilities variables (X2), statistically show insignificant results on employee turnover intention at the Travelodge Batam Hotel. This can be seen from the significant work facility training (X2) $0.972>0.05$ with a t-score of -0.035 .

The leadership variable (X3) statistically shows insignificant results on employee turnover intention at the Travelodge Batam Hotel. This can be seen from the insignificant leadership (X3) 0.399 > 0.05 . With the calculated value of -0.852 .

The reward variable (X4) shows statistically significant results on employee turnover intention at the Travelodge Batam Hotel. significant award (X4) $0.000<0.05$. With the $\mathrm{t}$ value of -4.417 . The hypothesis is accepted. The reward variable has a significant effect on employee turnover intention at the Travelodge Batam Hotel. This shows, every single act of reward given by the Travelodge Batam Hotel to employees will reduce employee turnover intention.
The job satisfaction variable (X5) has a statistically have significant effect on employee turnover intention at the Travelodge Batam Hotel. This can be seen from the significant job satisfaction (X5) $0.008<0.05$. The $t$ value is -1.277 . This shows, any increase in job satisfaction of job satisfaction given by the Travelodge Batam Hotel to employees will reduce employee turnover intention.

The organizational culture variable (X6) has a statistically insignificant effect on employee turnover intention at the Travelodge Batam Hotel. This can be seen from the significant organizational culture (X6) $0.510>0.05$. With the value of $t$ count the number 0.664

\section{DISCUSSION}

Based on the results of the study, there are six (6) factors that are expected to affect employee turnover intention at Travelodge Batam Hotel, these factors are: salary factor, training and work facilities factor, leadership factor, reward factor, job satisfaction factor and organizational culture factor. This shows that external or organizational factors such as salary, training and work facilities, leadership, rewards and organizational culture are more dominant in influencing employee turnover intention at Travelodge Batam Hotel. These external factors can make employees less satisfied with their work, thus reducing employee performance (Harris, Lavelle, and McMahan 2020).

Furthermore, the results of multiple regression analysis show that among the six factors there are only two (2) factors that have a significant effect, namely the reward factor and the job satisfaction factor.

The reward factor has a regression coefficient of -1.067 , so every increase of 1 unit of reward given to employees at Travelodge Batam Hotel will reduce the employee's intention to leave the organization by 1.067 units. Reducing the interest of employees to leave the organization is important for organizational continuity (Kim, N., 2014). For this reason, companies need to give more appreciation to employees who are performing well.

Giving rewards to employees that are not only in the form of material, but can also be in the form of praise, congratulations, as a form of selfactualization for the employee.

While the job satisfaction factor has a regression coefficient of -0.348 , thus every 1 unit increase in job satisfaction felt by Travelodge Batam Hotel employees can reduce employee turnover intention by 0.348 units. The satisfaction felt by employees at work can improve employee performance (Sabuhari, R., Sudiro, A., Irawanto, D \& Rahayu, M., 2020). 
Employees who are satisfied with their work will have more loyalty to the company where they work (Swati, Tanusree, and Piyali 2020), automatically this will reduce the employee's intention to leave the organization.

While the factors of salary, training and work facilities, leadership and organizational culture do not have a significant effect on employee Intention turnover at Travelodge Batam Hotel. The results of this study contradict the results of the study (Forendes, Adrian, and Fiza 2020), which states that work facilities have a significant effect on employee intention turnover.

\section{CONCLUSION}

Based on the factor analysis, the factors that influence employees are developed into 35 indicators to see their effect on turnover intention at the Travelodge Batam Hotel. These indicators are analyzed using factor analysis to reduce the data into a data structure that is simple to interpret, so there are 6 factors that influence turnover intention at the Travelodge Batam Hotel. The factors that influence employees on turnover intention at the Travelodge Batam Hotel are as follows:

1) The salary factor is the factor that most influences employees, because it has the greatest eigenvalue and variable variability.

2) The factors of training and work facilities are in the second place that affect employees.

3) The leadership factor is in the third place that affects employees

4) The reward factor is in the fourth place that affects employees

5) Job satisfaction factor, is in the fifth order that affects employees

6) Organizational culture factors are in the last order of the factors that affect employees in making turnover intention at the Travelodge Batam Hotel.

\section{REFERENCES}

Abraham H. Maslow, 2010, Motivation and Personality.Rajawali,Jakarta

Forendes, Nindi. Arif Adrian, and Adek Kurnia Fiza. 2020. "Pengaruh Fasilitas Kerja Karyawan Terhadap Turnover Intention di Imelda Hotel Waterpark-Convention Padang." Jurnal Kajian Pariwisata dan Bisnis Perhotelan
2(1):96-100.

https://doi.org/10.24036/jkpbp.v1i2.9172

Griffeth R W. PW, Hom and S. Gaertner. 2010. A MetaAnalysis of Antecedents and Correlates of Employee Turnover Update, Moderator Test and Research Implication fort the Next Millenium. Journal of Management. 26 (3): 463-488.

Harris, Christopher M., James J. Lavelle, and Gary C. McMahan. 2020. "The Effects of Internal and External Sources of Justice on Employee Turnover Intention and Organizational Citizenship Behavior toward Clients and Workgroup Members." The International Journal of Human Resource Management 31(17):2141-64. https://doi.org/10.1080/09585192.2018.1441 163

Hasibuan, Malay. 2011. Human Resources and Management. Revised Edition. Jakarta: Earth Literacy.

Kim, N. (2014), Employee Turnover Intention Among Newcomers in Travel Industry. Int. J. Tourism Res., 16: 56-64. https://doi.org/10.1002/jtr.1898

Mathis Robert L. and John H. Jackson. 2009. Human Resource Management: Salemba.empat

Mobley,WH2012. Substitution of Employees: Causes,Effects and Control. Translate. jakarta:PT Pustaka Binaman/Pressindo.

Rivai, Veithzal and Sagala, Ella Jauvani. 2011. Human Resource Management for Companies: From Theory to Practice. Jakarta: PT Raja GrafindoPersada.

Sabuhari, R., Sudiro, A., Irawanto, D \& Rahayu, M. (2020). The effects of human resource flexibility, employee competency, organizational culture adaptation and job satisfaction on employee performance.Management Science Letters, 10(8), 1775-1786.

Sedarmayanti. 2011. Work Procedure / and Work Productivity.Bandung,Mandar/Advanced

Sunyoto, D. (2012). Management / Resources / Human, mold 1. Yogyakarta: CAPS.

Sugiyono. 2013. / Quantitative,Qualitative and R\&D Research Methods. Alphabet.

Wibowo.2013. Performance Management, $3^{\text {rd }}$ edition. Jakarta,/Rajaweali press. 